\title{
Assessment of performance and parameter sensitivity of multicomponent geothermometry applied to a medium enthalpy geothermal system
}

\author{
Fabian Nitschke ${ }^{1 *}$, Sebastian Held ${ }^{1}$, Ignacio Villalon ${ }^{2}$, Thomas Neumann ${ }^{1}$ and Thomas Kohl ${ }^{1}$
}

${ }^{*}$ Correspondence:

fabian.nitschke@kit.edu

${ }^{1}$ Institute of Applied

Geosciences (AGW)

at Karlsruhe Institute

of Technology, Karlsruhe,

Germany

Full list of author information

is available at the end of the

article

\begin{abstract}
The determination of reservoir temperatures represents a major task when exploring geothermal systems. Since the uncertainties of classical solute geothermometry are still preventing reliable reservoir temperature estimations, we assess the performance of classical geothermometers and multicomponent geothermometry by applying them to fluids composed from long-term batch-type equilibration experiments and to fluids from natural geothermal springs in the Villarrica area, Southern Chile. The experiments, weathering two reservoir rock analogues from the Villarrica area, highlight a strong impact of reservoir rock composition on the fluid chemistry and, consequently, on calculated in situ temperatures. Especially temperatures calculated from classical solute geothermometry are strongly affected. Multicomponent geothermometry is obviously more robust and independent from rock composition leading to significantly smaller temperature spreads. In a sensitivity analysis, the dilution of geothermal fluid with surficial water, the $\mathrm{pH}$ and the aluminum concentration are anticipated to be the factors causing underestimations of reservoir temperatures. We quantify these parameters and correct the results to obtain realistic in situ conditions. Thus, enabling the application of the method also on basis of standard fluid analysis, our approach represents an easyto-use modification of the original multicomponent geothermometry leading to very plausible subsurface temperatures with significantly low scattering.
\end{abstract}

Keywords: Multicomponent geothermometry, Classical solute geothermometers, Laboratory alteration experiments, Villarrica geothermal system

\section{Background}

The estimation of reservoir temperatures is a major goal in geothermal exploration. The in situ temperature is a key parameter for the assessment of geothermal potentials and the economic efficiency of prospected reservoirs. Deducing these temperatures from the chemical composition of geothermal fluids emerging at the earth's surface is a commonly used and relatively cost-effective method. Over more than five decades a large number of solute geothermometers have been established and constantly improved [e.g., Fournier and Rowe (1966), Giggenbach (1988), Can (2002), Sanjuan et al. (2014)]. Many of these interrelations, linking the concentration of one constituent or the ratios 
of cations $\left(\mathrm{SiO}_{2}, \mathrm{Na} / \mathrm{K}, \mathrm{K} / \mathrm{Mg}, \mathrm{Na} / \mathrm{K} / \mathrm{Ca}\right)$ to the in situ temperature, are based on rather well known water-rock interaction processes (silica solubility, cation exchange in the feldspar system and equilibria of micas). Furthermore, empirical geothermometers using the ratios of $\mathrm{Na} / \mathrm{Li}$ and $\mathrm{Mg} / \mathrm{Li}$ (Fouillac and Michard 1981; Kharaka and Mariner 1989; Sanjuan et al. 2014) has been established, additionally accounting for fluid salinity, chloride concentration and the geology of the reservoir. However, solute geothermometry still is afflicted with great uncertainties often leading to a broad range and often inconsistent calculated reservoir temperatures (Santoyo and Díaz-González 2010; Verma and Santoyo 1997), in particular exploring geothermal systems, where only few information (geology, borehole data etc.) is available. Even in studies in which the individual geothermometers has been carefully selected regarding their applicability and validity for the expected conditions, the resulting temperatures show variations of often more than $100 \mathrm{~K}$ for the same sample (e.g., Pepin et al. 2015; Aquilina et al. 2002; Mutlu 1998; D’Amore et al. 1994).

Recently, a number of geochemical surveys have evaluated the in situ temperatures of the geothermal system in the Villarrica area in Southern Chile, where many natural geothermal springs discharge in direct vicinity of the active Villarrica volcano. The estimations of subsurface temperatures resulted in widely differing and even inconsistent data. Sánchez et al. (2013) roughly determined temperatures of $100-180{ }^{\circ} \mathrm{C}$ from cation ratio geothermometers, with the warmest temperatures close to the volcanoes. Whereas, estimations based on the temperature-dependent oxygen isotope fractionation in the system $\mathrm{SO}_{4}{ }^{2-}-\mathrm{H}_{2} \mathrm{O}$ (Held et al. 2015), temperatures ranging from 80 to $130{ }^{\circ} \mathrm{C}$, are significantly lower. Although, in a previous work from these authors (Nitschke et al. 2016), the warmer temperatures of the first study (in the North) as well as the cooler of the latter (in the South) were partly confirmed, the results were accompanied with large uncertainties for the individual springs of up to $130 \mathrm{~K}$. Temperature estimations with uncertainties of that level are unsatisfactory for reliable exploration.

Many factors interfering precise and consistent results have been identified and discussed in literature. For calculating reservoir conditions based on the solubility of only one mineral phase (e.g., $\mathrm{SiO}_{2}$ geothermometers), the amount of solvent has to remain constant from reservoir to the discharge. Therefore, dilution with superficial water and boiling due to pressure relief are often considered to have greatest impact. For cation ratio geothermometers, which are not affected by changes of the amount of solvent, other processes like immaturity (not yet attained water-rock equilibrium) of fluids, fast re-equilibration kinetics and precipitation during ascent prevent from obtaining true in situ temperatures. The role of the reservoir lithology, as a major interfering factor becomes obvious, when for example comparing studies from, e.g., Giggenbach (1988), Arnórsson (2000), Fournier (1979) and Fournier und Truesdell (1973), indicating rather large discrepancies of the $\mathrm{Na} / \mathrm{K}$ ratios of fluids from equilibrated geothermal systems of different lithologies for a given system. The same applies to other cation ratios $(\mathrm{Na} / \mathrm{K} / \mathrm{Ca}$, $\mathrm{K} / \mathrm{Mg}, \mathrm{Na} / \mathrm{Li}$, etc.), commonly used for geothermometry. Also the authors of this study have previously found strong indications for the significant effect of different reservoir lithologies on the hydrochemical composition of the fluids affecting the calculation of reservoir temperatures (Meller et al. 2016; Nitschke et al. 2015; Nitschke et al. 2016). In this work, laboratory experiments are conducted to investigate the site-specific impact 
of rock composition on the equilibrated fluids in detail and to deduce implications for classical solute geothermometer applications. Furthermore, the numerical multicomponent geothermometry method as proposed originally by Reed and Spycher (1984) is assessed, evaluating if its statistical nature can overcome dependence upon reservoir rock composition. In order to facilitate the application of multicomponent geothermometry on basis of a standard fluid analysis, we suggest an easy-to-use modification of the original method.

\section{Methods and results}

The detailed geological setting of the study area is documented in previous works of Held et al. (2016b) and Sánchez et al. (2013). They found a prominent change of lithology associated with the virtually E-W striking Mocha-Villarrica-Fault Zone. South of that fault plutonic rocks of the North Patagonian Batholith (NPB) prevail, while to the north mainly volcanic and volcano-clastic rocks of the Cura-Mallin (CM) formation outcrop. Depending upon this local lithology change, strontium isotope measurements (Held et al. 2015) reveal spatially differing geothermal fluids, with a plutonic signature south of the volcanic chain and a volcanic signature in the north of the study area. Accordingly, for the experimental approach, two reservoir rock analogues were selected, representing the two different geological units: a Mesozoic tonalite (NPB) and a Cenozoic porphyric andesite $(\mathrm{CM})$ for long-term batch reaction experiments.

Usually, reservoir rocks and their compositions are poorly known during exploration of a geothermal system and effects of different mineralogical compositions on geothermometers are difficult to handle. By calculating the equilibration temperature of a large number of (reservoir) rock forming minerals, multicomponent geothermometry provides a more statistical approach of determining in situ temperatures. Therefore, this method is more unbiased from reservoir rock composition. To test this hypothesis, we apply the method on natural emerging geothermal fluids from the Villarrica area and on the fluids derived from laboratory experiments to compare the results to temperatures calculated with classical solute geothermometers.

\section{Laboratory water-rock equilibration experiments}

A tonalite and the andesite were chosen for the experiments as they were presumed to be the most likely reservoir rocks for the natural geothermal fluids due to their spatial distribution in the study area. Prior to the water-rock interaction experiments, the mineral compositions of both rock samples were analyzed in detail. The quantification of the mineral assemblages [vol.\%], derived from thin-section microscopy and X-ray diffraction (Siemens D500) are given in Table 1. The absence of K-feldspar in the tonalite and the differing $\mathrm{SiO}_{2}$ polymorphs (only chalcedony in the andesite and only quartz in the tonalite) are of particular importance in terms of geothermometry.

The experimental setting described below was designed according to the findings from several test runs leading to a progressive refinement of the laboratory procedure due to an increasing expertise. In order to reduce reaction time towards equilibrium to a minimum, the reactive surface was enlarged by grinding the rock samples with an agate disc mill to a grain size $<63 \mu \mathrm{m}$. After that treatment, the surface area of both samples is in the same order of magnitude (tonalite: $2.1 \mathrm{~m}^{2} / \mathrm{g}$, andesite: $3.6 \mathrm{~m}^{2} / \mathrm{g}$ ) as revealed by BET 
Table 1 Volumetric mineral composition of reservoir rock analogues used for laboratory experiments

\begin{tabular}{lll}
\hline & Tonalite [vol.\%] & Andesite [vol.\%] \\
\hline Quartz & 50 & - \\
Chalcedony & - & 5 \\
K-feldspar & - & 5 \\
Plagioclase & 25 & 40 \\
Pyroxene & - & 30 \\
Serizite & 10 & - \\
Muscovite & $<5$ & - \\
Chlorite & $<5$ & $<5$ \\
Biotite & 10 & - \\
Clay minerals & - & 10 \\
Magnetite & - & 10 \\
\hline
\end{tabular}

measurements. Then, $40 \mathrm{~g}$ of rock powder was transferred to a hermetic stainless-steel batch reactor. Avoiding any head space, the vessel $(150 \mathrm{~mL})$ was then completely filled up with pure $\mathrm{H}_{2} \mathrm{O}$. The rock-water ratio was $\sim 0.3$. The reaction temperature was chosen to be $140{ }^{\circ} \mathrm{C}$, which is the anticipated mean reservoir temperature in the study area. To control the development of fluid composition over time and to enable the identification of steady state conditions, the experiments were sampled and analyzed in a time series after 1, 2, 4, 6, 10, 20, 30, 45, 60, 90, 120, and 180 days (Fig. 1). Each time step represents an autonomous experiment and therefore ensures the reproducibility of results. After termination of the experiments, fluids were centrifuged and filtered (cellulose acetate membrane, pore size $<0.45 \mu \mathrm{m}$ ). In order to stabilize the solution (preventing supersaturated phases from precipitation), an immediate dilution of the cooled sample with pure $\mathrm{H}_{2} \mathrm{O}$ is of particular importance. The fluid composition was measured using inductively coupled plasma mass spectrometry (Thermo Fisher, X-Series2) for the cations and ion chromatography (Dionex, ICS-1000) for the anions. Silicon concentrations were determined by spectrophotometry (PerkinElmer Lambda 2S).

The chemical evolutions of the major constituents over time are depicted in Fig. 1 and in a tabular form in Appendix. Measured aqueous constituents are assumed to be present as a result of water-rock interaction. Due to the fact, that only low mass transfer occur for both experiments, the minerals being educts and products of fluid-solid reactions were not determined (resulting changes of solids were below the detection limit of XRD ( $<5$ mass\%) and SEM-EDX (very thin alteration products). Therefore, conclusions made in terms of geothermometric applications, are based on changes of water chemistry only. Comparing both experiments, significant differences in fluid compositions become obvious. Towards the end of the reaction time, the fluid in contact with tonalite has a TDS of about $700 \mathrm{mg} / \mathrm{L}$, whereas the TDS of the fluid from the andesite experiment is about $500 \mathrm{mg} / \mathrm{L}$. The tonalite fluid can be classified as a $\mathrm{Na}-\mathrm{SO}_{4}$ fluid of near neutral $\mathrm{pH}$ (6.7), while the andesite fluid is a $\mathrm{Na}-\mathrm{Cl}$ fluid with a higher $\mathrm{pH}$ of 8.5. Sodium concentrations are very similar $(5-6 \mathrm{mmol} / \mathrm{L})$ for both experiments at the end of the reaction time, with a nearly continuous, but diminishing increase over time. The tonalite fluid is found to have high concentrations of potassium and calcium at early stages, but decreasing over the duration of the experiment. The andesite fluid is showing 

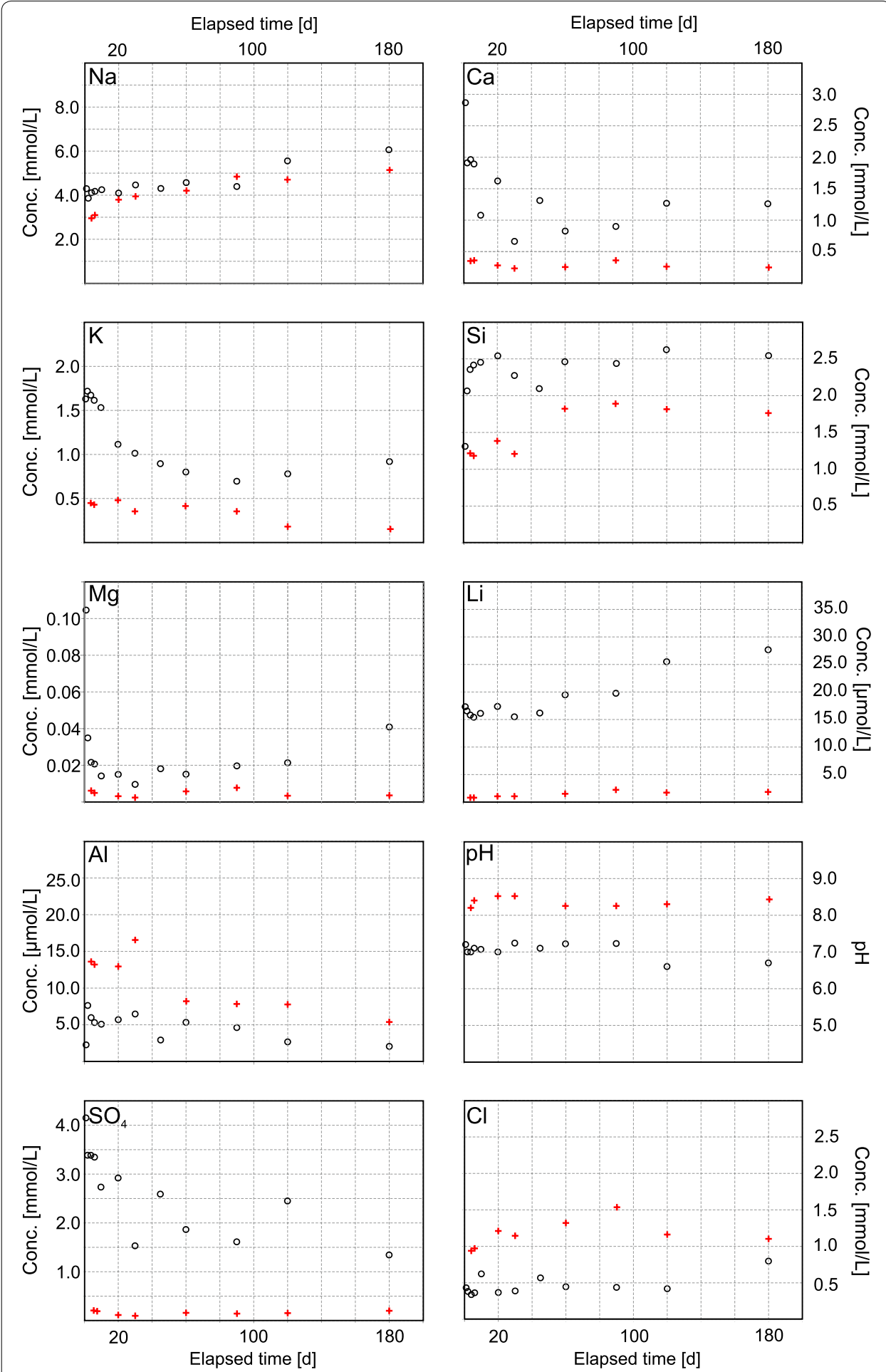

Fig. 1 Temporal development of concentrations of major constituents ( $\mathrm{Na}, \mathrm{K}, \mathrm{Ca}, \mathrm{Mg}, \mathrm{Li}, \mathrm{Si}, \mathrm{Al}, \mathrm{SO}_{4}, \mathrm{Cl}$ and pH) of the laboratory equilibration experiments plotted versus elapsed reaction time (tonalite experiments black circles, andesite experiments red crosses) 
relatively constant concentrations for both cations, but remaining on a significantly lower level compared to the tonalite fluid. Aqueous $\mathrm{SiO}_{2}$ concentrations of both fluids reach a steady state already in relatively early stages of the experiments (after 4 days for the tonalite fluid, after 45 days for the andesite fluid). However, they differ strongly from each other. Being hardly explainable, although, we observe that the andesite fluid saturates with respect to quartz, whereas the chalcedony saturation of the tonalite fluid, leads to significantly higher $\mathrm{SiO}_{2}$ concentrations.

Applying these results to geothermometry, the consequences for $\mathrm{SiO}_{2}$ geothermometers are becoming obvious (Fig. 2),-resulting in over-or underestimations of about $20 \mathrm{~K}$ (for the given reaction temperature of $140{ }^{\circ} \mathrm{C}$ ). But also for further geothermometers, the reservoir rock composition affects temperature estimations. The application of $\mathrm{Na} /$ K geothermometer equations lead to even significantly higher discrepancies (Fig. 2). Formulations of Arnórsson (1983) or Fournier and Truesdell (1973) work very well for the andesite fluids approaching the reaction temperature of $140{ }^{\circ} \mathrm{C}$ towards the end of

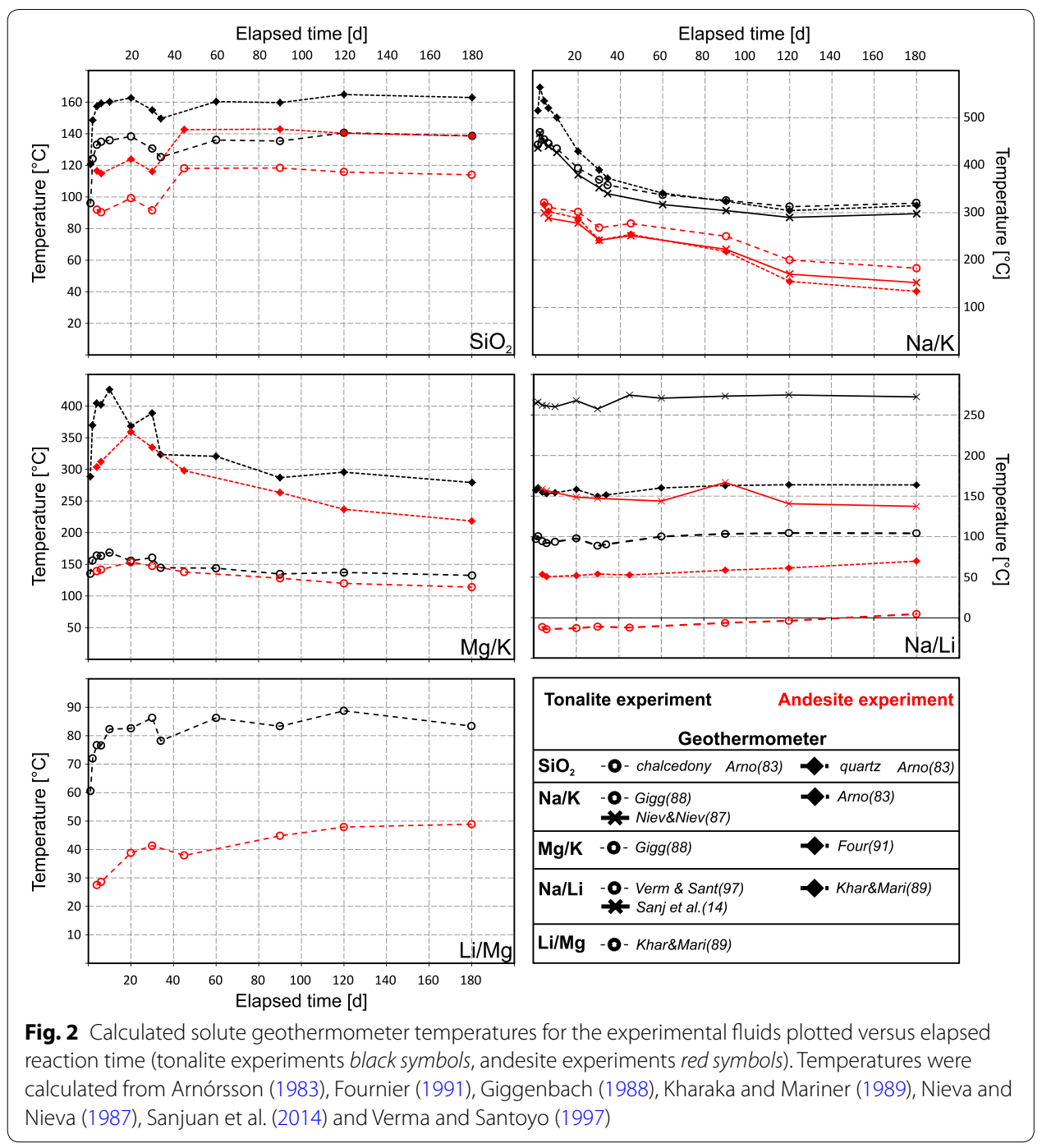


the experiments, whereas the temperature of the tonalite fluids is strongly overestimated with temperatures of $>300^{\circ} \mathrm{C}$. This failure may be explained by the absence of $\mathrm{K}$-feldspar in the tonalite and therefore the $\mathrm{Na} / \mathrm{K}$ equilibrium in this case is controlled by other potassium phases (e.g., muscovite), leading to a relative potassium enrichment, which results in that significant temperature overestimation.

The $\mathrm{Mg} / \mathrm{K}$ geothermometer of Giggenbach (1988) estimates reaction temperatures for both experiments quite well. Especially for the tonalite fluids, the calculated temperature $\left(137^{\circ} \mathrm{C}\right)$ reflects the reaction conditions in nearly perfect agreement. For the andesite fluids calculated temperatures approach reaction temperature over the course of the experiments, but decrease to slightly underestimated temperatures towards the end $\left(120^{\circ} \mathrm{C}\right) . \mathrm{Na} / \mathrm{Li}$ based temperature determination (Kharaka and Mariner 1989; Sanjuan et al. 2014; Verma and Santoyo 1997) is obviously rather less appropriate, giving a broad range of apparently erratic results depending upon experiment and applied formulation. The method leads to dramatic underestimated temperatures (Verma and Santoyo 1997) but also really well fitting results (Sanjuan et al. 2014) for the andesite experiment. Calculated temperatures for the tonalite fluids range from underestimations (Verma and Santoyo 1997) to high overestimations (Sanjuan et al. 2014). The Li/Mg geothermometer (Kharaka and Mariner 1989) underestimates the reaction temperature for both experiments to a great extent.

As the steady state of the fluids is a crucial point for further analysis, the chemical water-rock equilibrium is assessed considering the concentrations of $\mathrm{K}^{+}, \mathrm{Ca}^{2+}$ and $\mathrm{Mg}^{2+}$ (Fig. 3). The method was originally proposed by Giggenbach and Goguel (1989). In contrast to many other methods for the evaluation of water-rock equilibrium, which plot fluid data versus theoretical concentrations derived from solving geothermometer equations (Giggenbach 1988; Tassi et al. 2010), this approach is (beside of the $\mathrm{K}-\mathrm{Mg}$ geothermometer) taking account for the equilibrium of K-feldspar, K-mica, chlorite, calcite and silica (Hedenquist 1991). It is shown that the experimental fluids plot far away

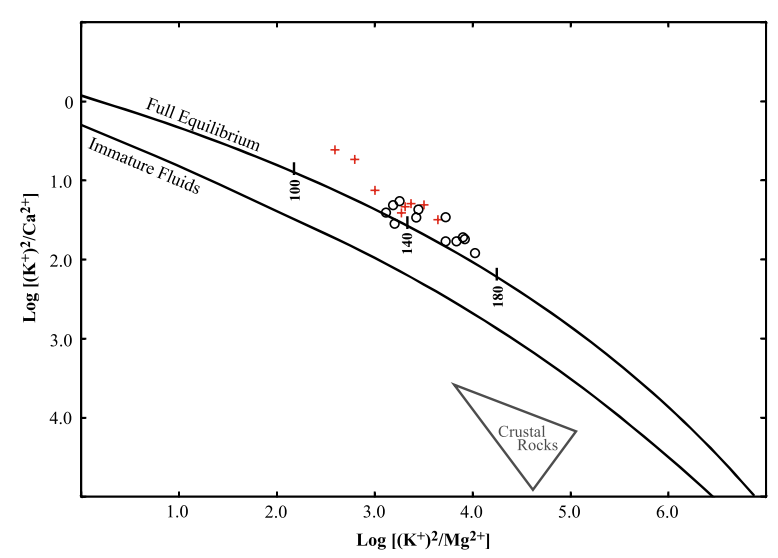

Fig. 3 Plot of $\mathrm{K}^{+} / \mathrm{Mg}^{2+}$ versus $\mathrm{K}^{+} / \mathrm{Ca}^{2+}$ ratios of the experimental fluids according to Giggenbach and Goguel (1989) (tonalite experiments black circles, andesite experiments red crosses), illustrating the near equilibrium state of the fluids 
from the state of initial crustal rock dissolution, but very close to the full equilibrium curve.

If the application of one geothermometer is successful, inaccurate or failing cannot be explained in every case (e.g., like for the $\mathrm{Na} / \mathrm{K}$ geothermometer). As laboratory procedures are identical for both experiments (sample preparation for solids and fluids and the setup of experiments), we conclude that the differences of fluid compositions comparing both experimental series in this specific case can only be due to the differences in rock composition. These discrepancies lead to different steady states of fluid compositions, which is consequently resulting in differences of calculated temperatures. Even if one of the geothermometers would yield a correct estimation of the reservoir temperature, there is no indication for the selection of that appropriate one when exploring a geothermal site.

\section{Multicomponent geothermometry}

The determination of in situ temperatures by multicomponent geothermometry, is based on the calculation of the saturation indices $(\mathrm{SI}=\log (Q / K))$ for a suite of possible (reservoir) rock minerals in a conceivable temperature interval. Based on a complete fluid analysis, an equilibrium temperature (temperature for which $\mathrm{SI}=0$ ) for each considered mineral phase is obtained. In contrast to classical solute geothermometry, the results represent a temperature distribution in which the fluid has been equilibrated with the host rock minerals. This enables the calculation of a mean in situ temperature from the bandwidth of obtained equilibration temperatures and gives insight on the uncertainty of this estimation (maximum spread of temperatures). From that point of view, multicomponent geothermometry can be considered as a statistical approach to predict reservoir temperatures and therefore it might be more applicable for the evaluation of systems with unknown mineralogy, which is often the case especially in early stages of geothermal exploration campaigns.

This study applies an approach similar to the original method suggested by Reed and Spycher (1984) and revisited by Spycher et al. (2014), Peiffer et al. (2014) and Palmer et al. (2014). Equilibration temperatures are calculated for feldspars (K-feldspars and albite), $\mathrm{SiO}_{2}$ polymorphs (quartz or chalcedony), phyllosilicates (muscovite, paragonite, biotites, kaolinite), zeolites and epidotes based on concentrations of major constituents $\mathrm{Na}, \mathrm{K}, \mathrm{Ca}, \mathrm{Si}, \mathrm{Al}, \mathrm{Fe}, \mathrm{Cl}$, alkalinity and sulfate. Magnesium phases are excluded intentionally, since dilution of geothermal fluids with superficial, Mg-rich waters will significantly bias reservoir temperature estimations, by overestimating equilibration temperatures for magnesium minerals. The determination of the critical parameters, such as in situ $\mathrm{pH}$ and aluminum concentration is done differently than in the above named studies. Contrasting the methods of Spycher et al. (2014) and Palmer et al. (2014), we determine in situ $\mathrm{pH}$ as a sum parameter via a sensitivity analysis ("In situ $\mathrm{pH}$ value" section), thus accounting for measurement errors as well as for degassing and speciation-driven processes, which potentially affect the $\mathrm{pH}$. The same applies for aluminum concentrations ("Aluminum concentration" section). Differing from the FixAl method proposed by Pang and Reed (1998), the here presented approach determines the aluminum concentration by minimization of the equilibrium misfit for all considered alumino-phases not by forced equilibrium of one single mineral. Numerical calculations were conducted using 
PhreeqC version 3.1.4 (Parkhurst and Appelo 2013) and thermodynamic data of Delany and Lundeen (1991).

According to this, in situ temperatures were calculated for the wells Caranco (Car), Chihuio (Chi), Liquine (Liq), Liucura (Liu), Los Pozones (Poz), Menetue (Men), Palguin (Pal), Panqui (Pan), Rincon (Rin), Rinconada (RinCo), San Luis (SL) and Trancura (Tra), all located in the vicinity of the Villarrica volcano (Fig. 4). In a first run, the $\mathrm{SiO}_{2}$ polymorph was determined, to calculate the appropriate silica equilibration temperature. For further analysis ( $\mathrm{pH}$ - and aluminum sensitivity and for the final temperature determination) the polymorph, which yield the better fitting temperatures (smaller deviation to mean temperatures from total mineral assemblage) was applied. Chalcedony was applied to the three southernmost springs (Car, Chi and Liq) and to the tonalite experiment. In situ temperatures for all other samples were calculated for quartz. The fluid compositions were determined analogously to measurements of experimental fluids ("Laboratory water-rock equilibration experiments" section). The detailed chemical compositions (major constituents) are depicted in Appendix.

Figure 4 provides a comparison of temperatures derived from multicomponent geothermometry (preliminary temperatures without correction of dilution, $\mathrm{pH}$ and aluminum concentration) to results calculated by a suite $(n=23)$ of classical solute geothermometers $\left(\mathrm{SiO}_{2}, \mathrm{Na} / \mathrm{K}, \mathrm{Na} / \mathrm{K} / \mathrm{Ca}, \mathrm{K} / \mathrm{Mg}, \mathrm{Li} / \mathrm{Mg}\right.$ and $\mathrm{Na} / \mathrm{Li}$ geothermometers according to the equations given by Arnórsson (1983), Can (2002), Diaz-Gonzalez et al. (2008) Fouillac and Michard (1981), Fournier (1977, 1979), Fournier and Potter (1982), Fournier and Truesdell (1973), Giggenbach (1988), Kharaka and Mariner (1989), Michard (1990), Nieva and Nieva (1987), Tonani (1980), and Verma and Santoyo (1997). The results were depicted as boxplots, plotting the mean (median value) equilibration temperature, the lower and upper quartiles (comprising 50\% of all temperatures) and the lower and upper extremes. The ranges of temperatures for the springs in the Villarrica area and for the

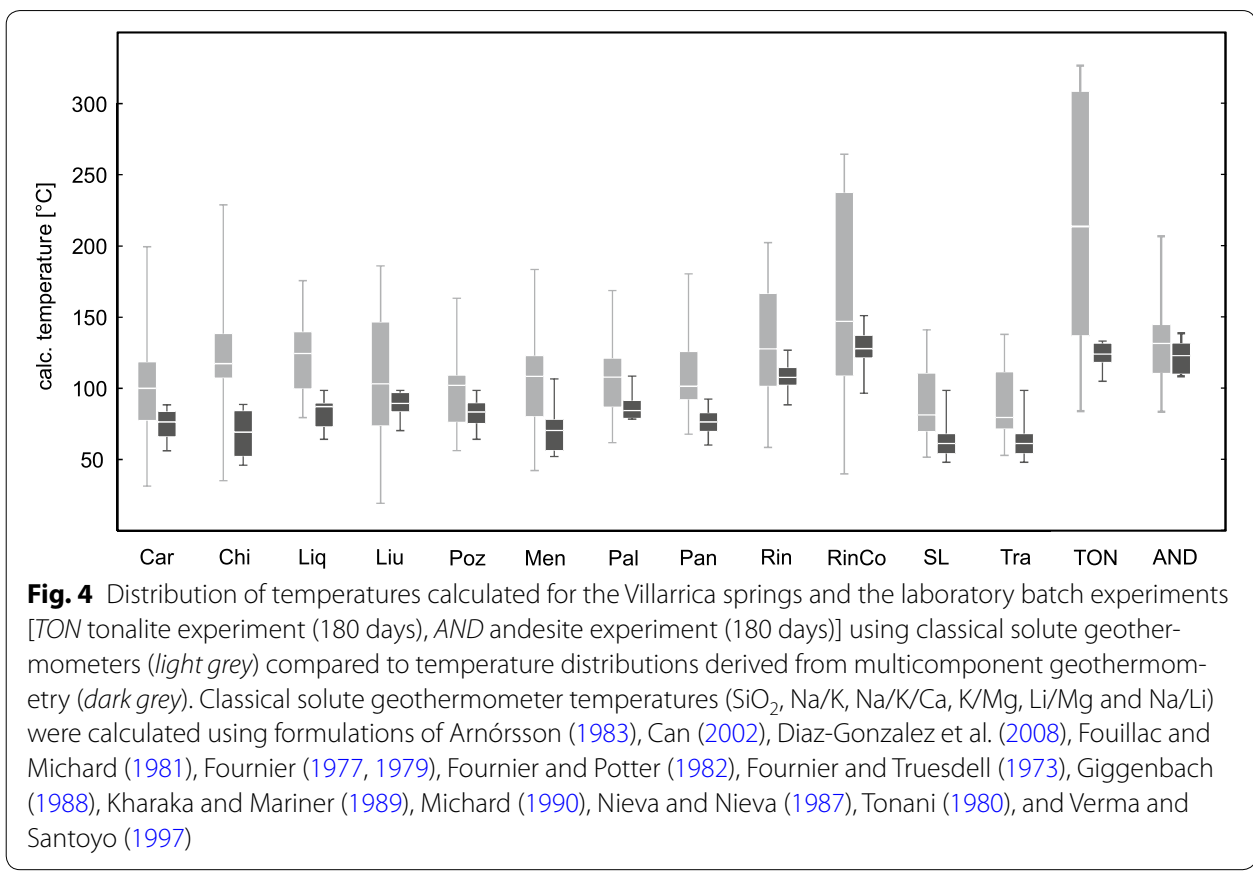


fluids derived from the experiments calculated by multicomponent geothermometry are significantly smaller as compared to the very large spread obtained from classical solute geothermometers. Despite special attention paid to the applicability of each solute geothermometer, it is shown that classical geothermometers generally lead to a broad spread of temperatures of, in some cases, $\gg 100 \mathrm{~K}$. The spread of temperatures derived from multicomponent geothermometry is much smaller.

At the same time, the calculated mean (median) temperatures are significantly lower. Although deviation of calculated temperatures for the experimental fluids is quite small $\left(124{ }^{\circ} \mathrm{C}\right.$ for the andesite experiment and $133^{\circ} \mathrm{C}$ for the tonalite experiments), estimations for some springs lead to implausible low values, ranging below the discharge temperature (e.g., discharge temperature/calc. temperature for $\mathrm{Car}=82 / 77^{\circ} \mathrm{C}$ or $\mathrm{Chi}=85 / 69^{\circ} \mathrm{C}$ ). At least in those cases temperatures are interfered by processes which were obviously not taken into account in this preliminary calculation. Generally, calculated temperatures appear to underestimate in situ temperatures, as in any case being significantly cooler compared to classical geothermometer temperatures. The identification and quantification of the critical parameters being most sensitive for the system and necessary corrections calculated realistic reservoir temperatures are presented in the following section.

\section{Discussion}

For the systematical underestimation of calculated temperatures discerned in "Multicomponent geothermometry" section, a number of processes or parameters are worth considering. Anticipated processes are the dilution with superficial water during ascent of fluids, the deviation of measured $\mathrm{pH}$ from in situ $\mathrm{pH}$ (due to degassing and as a function of temperature), as well as the uncertainties of aluminum concentrations (due to precipitations, sampling, sample storage and measurement errors). To quantify the impact of each parameter and to obtain realistic in situ conditions is a major task. Therefore, we conducted a sensitivity analysis on each of the mentioned parameters. In terms of the $\mathrm{pH}$ and the aluminum concentration, the best-fit results of this analysis (minimization of total temperature spread and densification of clustering of the majority of temperatures) are assumed to represent the most likely in situ conditions, which are then basis for the final temperature estimation.

\section{Dilution with superficial water}

On the basis of chlorofluorocarbon measurements (CFC-11, CFC-12 and CFC-113), which yield the degree of dilution of the fluids from the geothermal springs (Held et al. 2016a), the deep reservoir fluid composition is reconstructed. To obtain the original composition, a simple binary mixing model of the discharged fluid and the composition of the Lake Villarrica (representing the superficial water) according to Eq. (1) is applied.

$$
C_{r, i, j}=\frac{C_{m, i}+\left(x_{j} \cdot C_{s, i}\right)}{1-x_{j}}
$$

with concentration $C$ and dilution fraction $x$ for the reservoir fluid $r$, the chemical components $i$ and the springs $j$. 
To evaluate the impact of dilution (mixing) on calculated reservoir temperatures, equilibration temperatures for the sample compositions and the adjusted original reservoir fluid compositions are plotted versus their degree of dilution (Fig. 5). It is shown that the expected impact of dilution on reservoir temperature calculation is hardly notable. The spread of calculated temperatures shows no trend with the degree of dilution. The deviation of mean equilibration temperatures of the original reservoir fluid compared to the sample composition is very low, reaching maximum $\sim 15 \mathrm{~K}$ for sample Liu, which is the most highly diluted sample (1:1). At least in the presented case, where relatively low mineralized geothermal fluids occur (concentrations of most constituents of geothermal fluids and surficial waters range in the same order of magnitude), multicomponent geothermometry appears to be quiet robust against dilution. Applying this to highly mineralized fluids, the system may be more sensitive and hence temperature estimation uncertainty may increase.

\section{In situ $\mathrm{pH}$ value}

Among the reservoir rock forming minerals, (alumino-)silicates are of major importance. Beside of being dependent upon temperature, the solubility of silicates is also controlled by the $\mathrm{pH}$ of the solution. As a consequence of degassing of geothermal fluids (depressurization during ascent) and the cooling of the fluid, measured $\mathrm{pH}$ can strongly differ from in situ values affecting calculated multicomponent geothermometer temperatures. Due to an increasing solubility of silicates with increasing alkalinity, the application of an excessive elevated $\mathrm{pH}$ will lead to an underestimation of temperatures (Figs. 6, 7). Therefore, the $\mathrm{pH}$ is a crucial and critical system parameter to the same extent. In order to correct the measured $\mathrm{pH}$ to in situ conditions, numerical approaches have been established [e.g., Reed and Spycher (1984)], which require an extensive high-precision fluid analysis with respect to $\mathrm{pH}$-controlling species and parameters $\left(\mathrm{CO}_{2}, \mathrm{H}_{2} \mathrm{~S}\right.$, organics, redox condition, etc.). However, the majority of geochemical surveys and exploration campaigns usually only perform standard fluid sampling and analysis implying limitations in this regard. To enable the application also for standard fluid analysis, the determination of in situ $\mathrm{pH}$ and the subsequent correction of equilibration temperatures

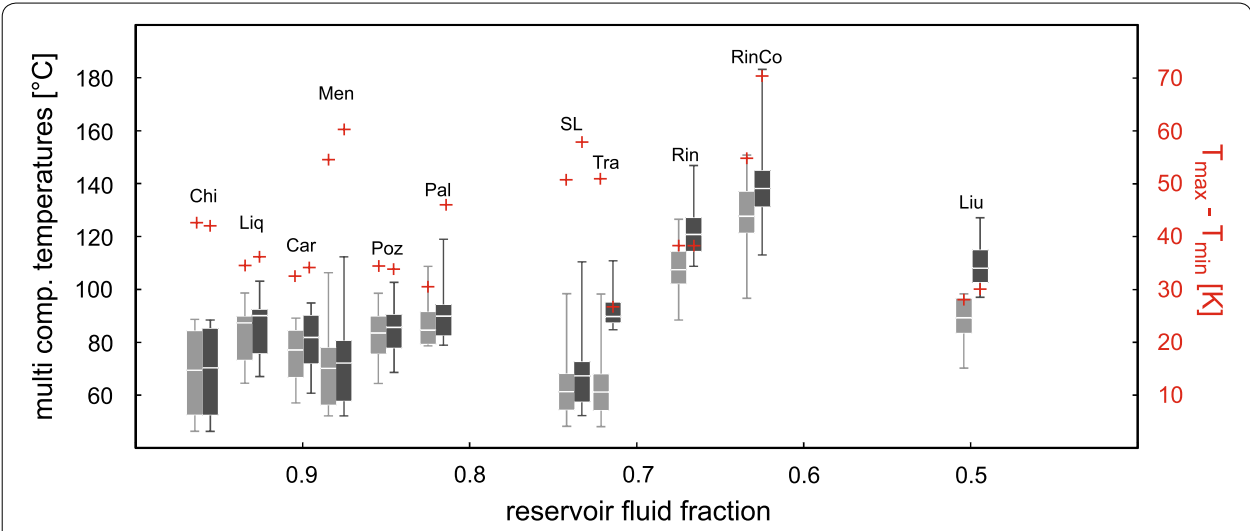

Fig. 5 Distribution of temperatures for the Villarrica springs calculated by multicomponent geothermometry for original sample compositions (light grey) and for dilution-corrected concentrations (dark grey) plotted versus degree of dilution. The spread of temperature $\left(T_{\max }-T_{\min }\right)$ is indicated by red symbols 

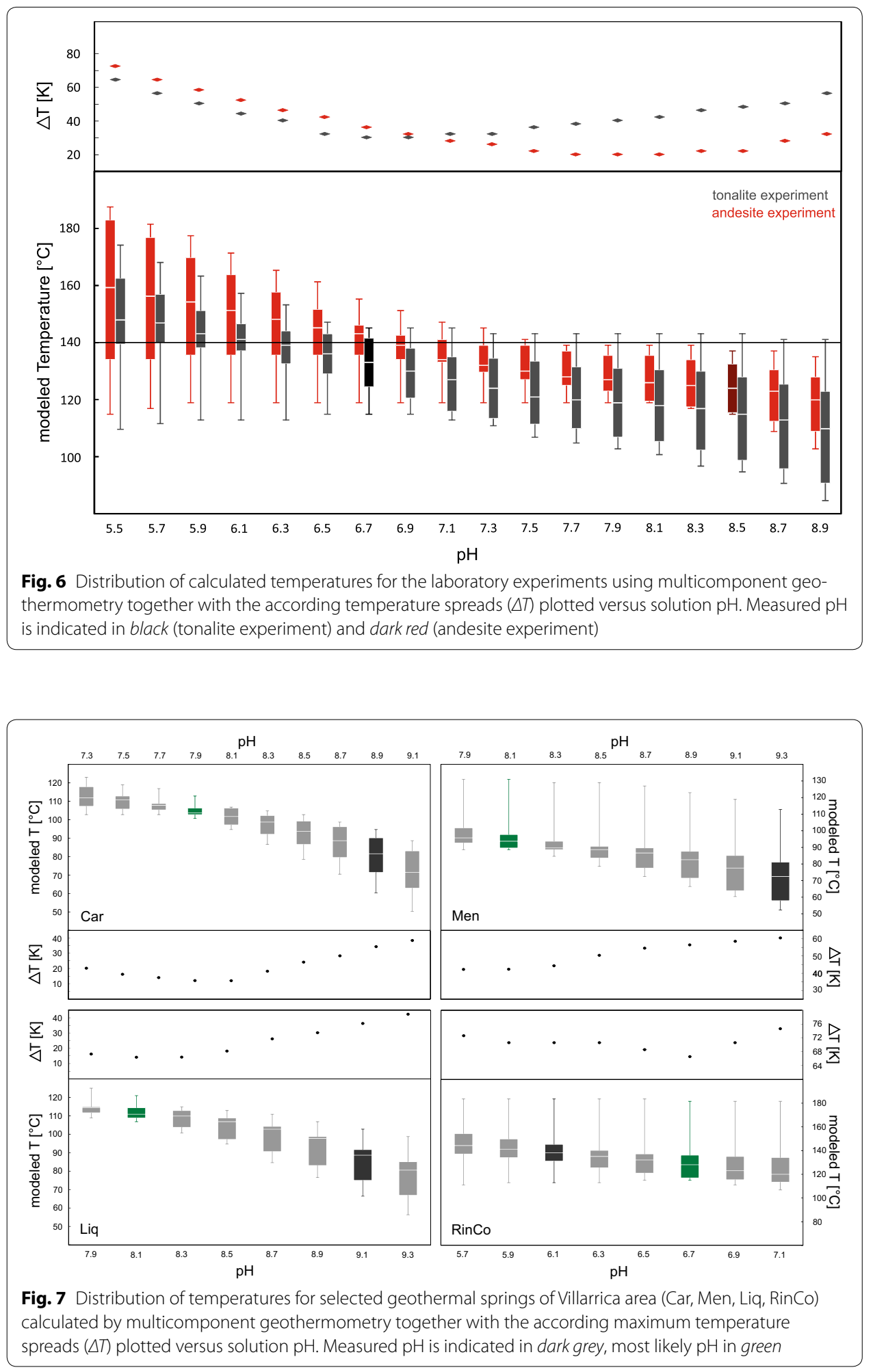
is done based on a numerical sensitivity analysis. In a first step, fluids derived from the laboratory experiments, where the reaction temperature is controlled and degassing can be excluded, were investigated (Fig. 6). It is shown that calculated temperatures reflect experimental conditions in a quite good agreement, being only slightly too low for both experiments for the measured $\mathrm{pH}$ values. Mean temperature for tonalite experiment at $\mathrm{pH} 6.7$ is 133 , and $124{ }^{\circ} \mathrm{C}$ for the andesite experiment at $\mathrm{pH} 8.5$. A decrease of $\mathrm{pH}$ reduces the equilibration temperature spread and slightly increases the calculated in situ temperature (Fig. 6). Considering the least temperature spread as the indication for the most likely in situ $\mathrm{pH}$, calculated mean temperature for the andesite experiment can be corrected to $130{ }^{\circ} \mathrm{C}$ at $\mathrm{pH} 7.5$. The measured near neutral $\mathrm{pH}$ of the tonalite experiment obviously already reflects conditions, which are close to reaction condition.

Variation of calculated equilibration temperatures as a function of $\mathrm{pH}$ can also be documented for the spring fluids (Fig. 7). Applying the measured $\mathrm{pH}$, the obtained temperatures appear to be too low (partly below discharge temperature, e.g., Car and Chi). Especially for samples with high measured $\mathrm{pH}$ (e.g., Car and Liq), which potentially reflects extensive degassing, a large temperature spread is obtained. Applying lower $\mathrm{pH}$ values results in an increase of modeled temperatures and a decrease of temperature spread. The minimum of the equilibration temperature spread (and secondly the clustering of the majority of calculated temperatures) was taken to determine the most likely in situ $\mathrm{pH}$, which then can be used to deduce the reservoir temperature. For samples with a measured slightly acidic $\mathrm{pH}$ (e.g., RinCo), modeled in situ $\mathrm{pH}$ will trend also towards neutral conditions resulting in a decrease of modeled mean temperature.

\section{Aluminum concentration}

Besides the $\mathrm{pH}$, also the aluminum concentration is a critical parameter effecting temperature calculations significantly. Being component of most fluid composition controlling minerals (alumino-silicates), correct aluminum concentrations are necessary to calculate reliable equilibration temperatures for those minerals (Table 2). Unfavorably, the determination of dissolved aluminum in geothermal fluids is often interfered by secondary processes during ascent of fluids (precipitation), sampling and sample handling

Table 2 Aluminum concentrations of Villarrica springs measured by ICP-MS in comparison to results of previous studies

\begin{tabular}{llll}
\hline Aluminum & This study [mmol/L] & Sánchez et al. (2013) [mmol/L] & Pérez (1999) [mmol/L] \\
\hline Car & 0.004 & $n / a$ & $n / a$ \\
Chi & 0.001 & 0.073 & $n / a$ \\
Liq & 0.005 & 0.040 & 0.004 \\
Liu & 0.002 & $n / a$ & 0.011 \\
Poz & 0.001 & $n / a$ & $b d l$ \\
Men & 0.002 & $n / a$ & 0.030 \\
Pal & 0.003 & 0.075 & 0.004 \\
Pan & 0.001 & $n / a$ & $n / a$ \\
Rin & 0.003 & 0.026 & $n / a$ \\
RinCo & 0.001 & $n / a$ & $b d l$ \\
SL & 0.001 & 0.013 & bdl \\
Tra & 0.004 & $n / a$ & bdl \\
\hline
\end{tabular}


(e.g., coagulant for silica gel formation and incorporation) in the laboratory (Brown 2013).

These issues are evident, when comparing aluminum concentrations of spring fluids in the study area measured in this study to results from previous works (Table 2). Results differ partly up to a factor of 20 , which will increase the saturation indices by $\sim 1.3$. Thus, aluminum concentrations (input parameter) were varied within the bandwidth of reported measured aluminum concentrations in the study area (Table 2). The $\mathrm{pH}$ values were set according to the findings from $\mathrm{pH}$ sensitivity analysis.

As anticipated, calculated mean equilibration temperatures increase with higher aluminum concentration (Fig. 8). Yet, the spread of temperatures is decreasing significantly until a minimum is reached. Also the majority of equilibration temperatures cluster in a smaller range. The best-fit in situ aluminum concentration is determined analogously to the in situ $\mathrm{pH}$ determination (least temperature spread). It can be shown that for the sample Car (Fig. 8) and the experimental fluids, measured aluminum concentrations already represent that best-fit aluminum concentrations, i.e., these fluids are in the state closest to equilibrium. The calculated temperatures for the majority of the spring fluids increase in the range of 10-35 K. Sample RinCo obviously, had been in a state of largest distance to equilibrium, resulting in $51 \mathrm{~K}$ warmer temperature estimation as a result of aluminum correction. Therefore, we suggest that, the consecutive correction of $\mathrm{pH}$ and aluminum concentration will lead to more realistic in situ temperatures. Equilibration temperatures which were determined in this way are displayed in Table 3. The multicomponent geothermometer approach, including the application of $\mathrm{pH}$ and aluminum concentration adjustments, seems to yield plausible temperature estimates, as the initially

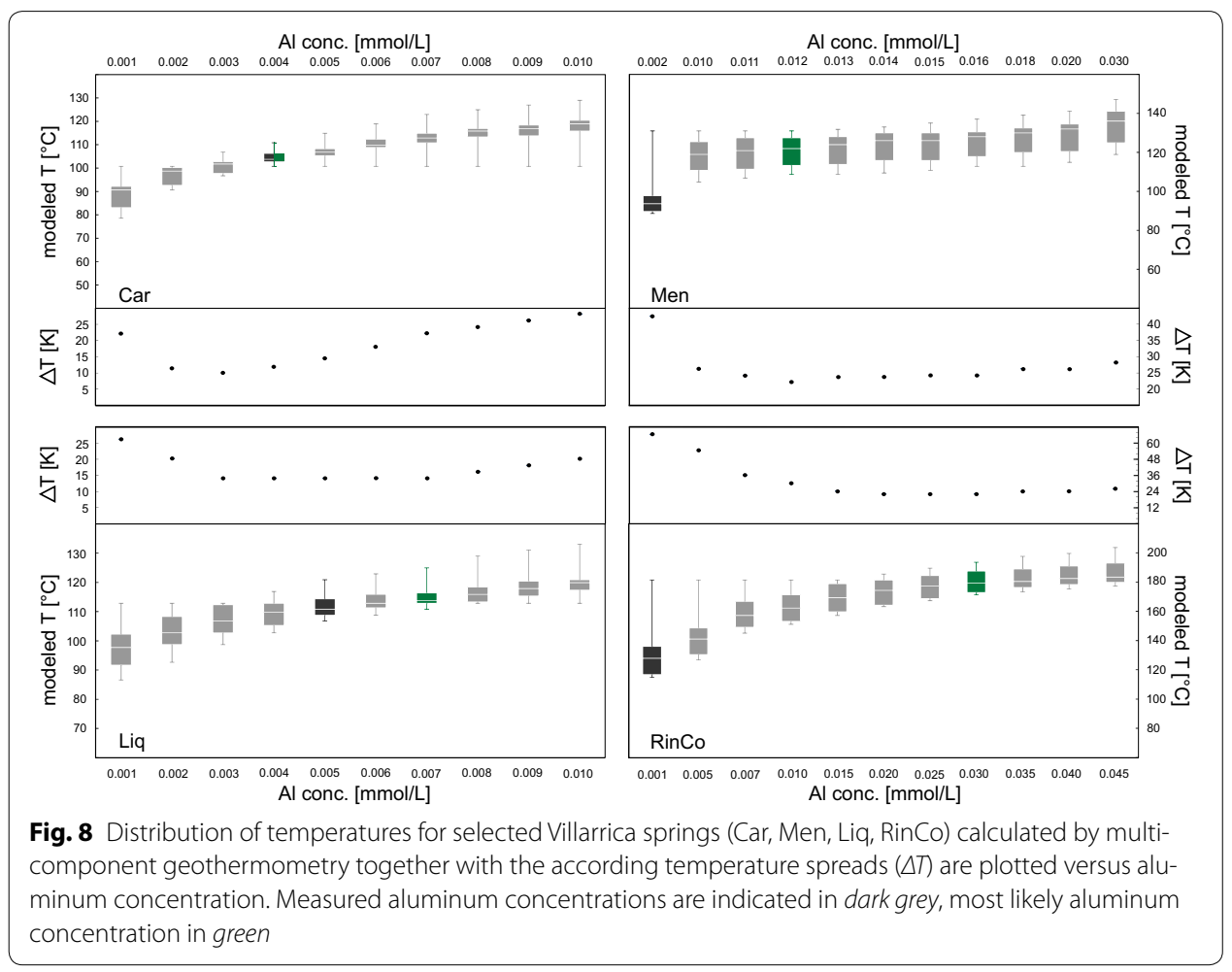


Table 3 Mean in situ temperatures for Villarrica springs and laboratory experiments calculated by a suite of classical solute geothermometers, multicomponent geothermometry and $\mathrm{pH} /$ aluminum-corrected multicomponent geothermometry

\begin{tabular}{|c|c|c|c|c|c|c|}
\hline \multirow[t]{2}{*}{ Spring } & \multicolumn{2}{|c|}{$\begin{array}{l}\text { Classical solute geothermom- } \\
\text { eters }\end{array}$} & \multicolumn{2}{|c|}{$\begin{array}{l}\text { Multicomponent geother- } \\
\text { mometer }\end{array}$} & \multicolumn{2}{|c|}{$\begin{array}{l}\text { Corrected multicompo- } \\
\text { nent geothermometer }\end{array}$} \\
\hline & Mean $T\left[{ }^{\circ} \mathrm{C}\right]$ & $\Delta T[\mathrm{~K}]$ & Mean $T\left[{ }^{\circ} \mathrm{C}\right]$ & $\Delta T[\mathrm{~K}]$ & Mean $T\left[{ }^{\circ} \mathrm{C}\right]$ & $\Delta T[\mathrm{~K}]$ \\
\hline Caranco & 100 & $(-69 /+99)$ & 77 & $(-20 /+12)$ & 102 & $(-5 /+5)$ \\
\hline Chihuio & 117 & $(-82 /+112)$ & 69 & $(-23 /+19)$ & 108 & $(-10 /+6)$ \\
\hline Liquine & 124 & $(-45 /+51)$ & 87 & $(-23 /+11)$ & 112 & $(-4 /+8)$ \\
\hline Liucura & 103 & $(-84 /+83)$ & 89 & $(-19 /+9)$ & 117 & $(-10 /+12)$ \\
\hline Los Pozones & 102 & $(-46 /+61)$ & 84 & $(-19 /+15)$ & 100 & $(-11 /+7)$ \\
\hline Menetue & 108 & $(-66 /+75)$ & 71 & $(-18 /+35)$ & 119 & $(-11 /+12)$ \\
\hline Palguin & 108 & $(-46 /+61)$ & 85 & $(-6 /+24)$ & 113 & $(-12 /+9)$ \\
\hline Panqui & 101 & $(-34 /+79)$ & 77 & $(-17 /+16)$ & 96 & $(-13 /+5)$ \\
\hline Rincon & 128 & $(-69 /+75)$ & 108 & $(-20 /+19)$ & 138 & $(-11 /+13)$ \\
\hline Rinconada & 147 & $(-40 /+118)$ & 128 & $(-32 /+23)$ & 179 & $(-8 /+14)$ \\
\hline San Luis & 81 & $(-30 /+60)$ & 61 & $(-13 /+37)$ & 117 & $(-17 /+7)$ \\
\hline Trancura & 80 & $(-27 /+59)$ & 61 & $(-13 /+37)$ & 108 & $(-14 /+10)$ \\
\hline Andesite exp. & 134 & $(-52 /+83)$ & 123 & $(-8 /+16)$ & 128 & $(-9 /+10)$ \\
\hline Tonalite exp. & 212 & $(-129 /+123)$ & 135 & $(-19 /+10)$ & 135 & $(-19 /+10)$ \\
\hline
\end{tabular}

rather low temperatures indicated by aluminum containing minerals increases and converge towards the initially significantly higher $\mathrm{SiO}_{2}$-phases temperatures. This is true for the natural geothermal fluids as well as for the already very accurate initial estimations of the laboratory experiments carried out at $140{ }^{\circ} \mathrm{C}$.

\section{Conclusions}

In many cases, the application of different classical solute geothermometer equations leads to a wide range of calculated temperatures. An important factor interfering consistent calculation are differences in reservoir rock composition and their impact on fluid chemistry. Long-term batch equilibration experiments in this study clearly show that reservoir rock composition has a major impact on temperatures calculated by classical solute geothermometry, with variations of $>200 \mathrm{~K}$. In order to overcome the strong dependence upon rock composition, we assess the statistical multicomponent geothermometer approach. Since the original method demands high quality fluid sampling and analysis, we suggest a modification, which can be used also on the basis of standard fluid analysis. Compared to classical solute geothermometry, the resulting calculated equilibration temperatures have a significantly smaller scattering for fluids of plutonic and volcanic origin in the investigated area. It is shown that the $\mathrm{pH}$ value and the aluminum concentration are extremely sensitive parameters for the calculation of equilibration temperatures on the basis of multicomponent geothermometers. Thus, as measured values for both parameters can differ significantly from in situ conditions, we suggest applying a correction for the $\mathrm{pH}$ and the aluminum concentration prior to temperature determination. In doing so, multicomponent geothermometry leads to more realistic mean temperature estimation with significantly low variances of mostly $\ll 30 \mathrm{~K}$ for the natural samples as well as for the experimental fluids. The well-fitting calculations of reaction temperatures for both experiments, reveal a higher independence from 
reservoir rock composition as compared to classical solute geothermometers. This could make multicomponent geothermometry an ideal complementary approach to classical solute geothermometer methods evaluating subsurface temperatures particularly in unknown lithologies. The general applicability to a wide range of reservoir rocks has to be proven in the next step. In terms of classical solute geothermometry, we conclude that the impact of reservoir rock composition is of outstanding importance and has to be taken into account in future applications.

\section{Authors' contributions}

$\mathrm{FN}$ — conception and design of the study, experimental work, analysis, modelling, paper writing. SH_experimental work, analysis, paper writing. IV-experimental work. TN-analysis, paper revision. TK-interpretation, paper revision. All authors read and approved the final manuscript.

\section{Author details}

${ }^{1}$ Institute of Applied Geosciences (AGW) at Karlsruhe Institute of Technology, Karlsruhe, Germany. ${ }^{2}$ Department of Geology, Facultad de Ciencias Fisicas y Matematicas, Universidad de Chile, Santiago, Chile.

\section{Acknowledgements}

The study is part of a collaborative research project of Karlsruhe Institute of Technology (KIT) and the Andean Geothermal Center of Excellence (CEGA, Fondap-Conicyt 15090013). The authors appreciate the support of the BMBF-CONICYT International Scientific Collaborative Research Program (FKZ 01DN14033/PCCI130025). Additional support under the topic "Geothermal Energy Systems" of the Helmholtz portfolio project "Geoenergy" and by EnBW Energie Baden-Württemberg AG is gratefully acknowledged. Many thanks to two anonymous reviewers, who helped to significantly improve the manuscript.

\section{Competing interests}

The authors declare that they have no competing interests.

\section{Availability of data and materials}

Data on which conclusions of the manuscript are based are presented in the text, otherwise they are adequately cited.

\section{Appendix}

See Table 4. 


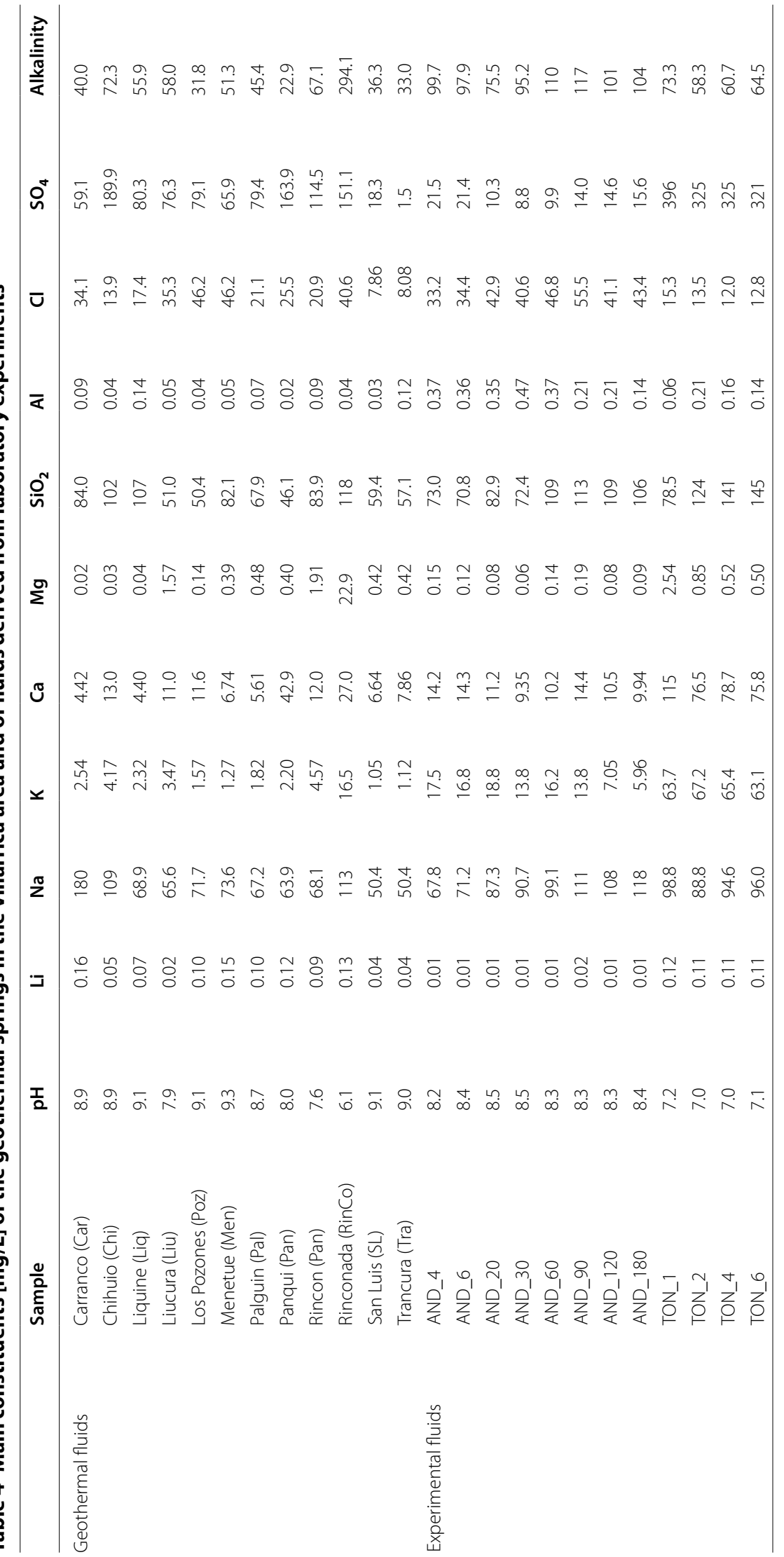




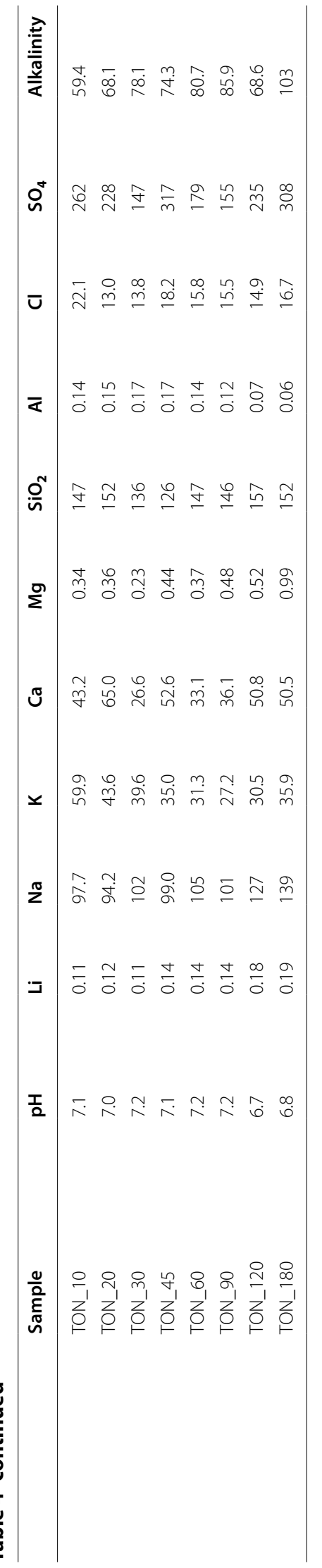




\section{Publisher's Note}

Springer Nature remains neutral with regard to jurisdictional claims in published maps and institutional affiliations.

Received: 17 March 2017 Accepted: 10 July 2017

Published online: 18 July 2017

\section{References}

Aquilina L, Ladouche B, Doerflinger N, Seidel JL, Bakalowicz M, Dupuy C, Le Strat P. Origin, evolution and residence time of saline thermal fluids (Balaruc springs, southern France): implications for fluid transfer across the continental shelf. Chem Geol. 2002;192:1-21.

Arnórsson S. Chemical equilibria in icelandic geothermal systems-implications for chemical geothermometry investigations. Geothermics. 1983;12:119-28.

Arnórsson S. Isotopic and Chemical Techniques in Geothermal Exploration, Development and Use. International Atomic Energy Agency: Vienna; 2000.

Brown K. Mineral scaling in geothermal power production: geothermal training programm. Reykjavik: United Nations University; 2013.

Can I. A new improved Na/K geothermometer by artificial neural networks. Geothermics. 2002;31(6):751-60.

D'Amore F, Gianelli G, Corazza E. The geothermal area of El Pilar-Casanay, state of Sucre. Venezuela. Geochemical exploration and model. Geothermics. 1994:23:283-304.

Delany JM, Lundeen SR. The LLNL thermochemical data base-revised data and file format for the EQ3/6 package. 1991.

Diaz-Gonzalez L, Santoyo E, Reyes-Reyes J. Tres nuevos geotermómetros mejorados de Na/K usando herramientas computacionales y geoquimiométricas: aplicación a la predicción de temperaturas de sistemas geotérmicos. Revista Mexicana de Ciencias Geológicas. 2008;25(3):465-82.

Fouillac C, Michard G. Sodium/lithium ratio in water applied to geothermometry of geothermal reservoirs. Geothermics. 1981;10(1):55-70.

Fournier RO. Chemical geothermometers and mixing models for geothermal systems. Geothermics. 1977:5:41-50.

Fournier RO. A revised equation for the Na/K geothermometer. Geotherm Resour Council Trans. 1979;3:221-4.

Fournier RO. Water geothermometers applied to geothermal energy. In: D'Amore F, editor. Applications of geochemistry in geothermal reservoir development. Italy: UNITAR, Rome; 1991.

Fournier RO, Potter RW. Revised and expanded silica (quartz) geothermometer. Geotherm Resour Counc Bull. 1982;11:3-12.

Fournier RO, Rowe JJ. Estimation of underground temperatures from the silica content of water from hot springs and wet-steam wells. Am J Sci. 1966;264:685-97.

Fournier RO, Truesdell AH. An empirical Na-K-Ca geothermometer for natural waters. Geochim Cosmochim Acta. 1973;37(5):1255-75

Giggenbach WF. Geothermal solute equilibria. Derivation of Na-K-Mg-Ca geoindicators. Geochim Cosmochim Acta. 1988:52:2749-65.

Giggenbach WF, Goguel RL. Collection and analysis of geothermal and volcanic water and gas discharges. 4th ed. New Zealand: Petone; 1989

Hedenquist JW. Boiling and dilution in the shallow portion of the Waiotapu geothermal system, New Zealand. Geochim Cosmochim Acta. 1991:55:2753-65.

Held S, Schill E, Pavez M, Diaz D, Morata D, Kohl T. Tectonic control of the geothermal system at Mt. Villarrica—insights from geophysical and geochemical surveys. In: Chilean Geological Conference 2015, La Serena, Chile; 2015.

Held S, Schill E, Pavez M, Diaz D, Morata D, Kohl T. Effects of major fault zones on geothermal reservoirs—a case study at Villarrica Volcano, southern Chile. In: Proceeding European Geothermal Congress 2016, Strasbourg; 2016 a.

Held S, Schill E, Pavez M, Díaz D, Muñoz G, Morata D, Kohl T. Resistivity distribution from mid-crustal conductor to nearsurface across the 1200 km long Liquiñe-Ofqui Fault System, southern Chile. Geophys J Int. 2016;207(3):1387-400.

Kharaka YK, Mariner RH. Chemical geothermometers and their application to formation waters from sedimentary basins. In: Naeser N, McCulloh TH, editors. Thermal history of sedimentary basins. New York: Springer; 1989.

Meller C, Bremer J, Ankit K, Baur S, Bergfeldt T, et al. Integrated research as key to the development of a sustainable geothermal energy technology. Energy Technol. 2016;5:1-44.

Michard G. Behaviour of major elements and some trace elements (Li, Rb, Cs, Sr, Fe, Mn, W, F) in deep hot waters from granitic areas. Chem Geol. 1990;89(1-2):117-34.

Mutlu H. Chemical geothermometry and fluid-mineral equilibria for the Ömer-Gecek thermal waters, Afyon area, Turkey. J Volcanol Geotherm Res. 1998;80:303-21.

Nieva D, Nieva R. Developments in geothermal energy in Mexico_-part twelve. A cationic geothermometer for prospecting of geothermal resources. Heat Recovery Syst CHP. 1987;7(3):243-58.

Nitschke F, Held S, Mundhenk N, et al. Reactivity of chilean reservoir rocks and the use of geochemical tools for reservoir characterization. In: Proceedings European Geothermal Workshop. European Geothermal Workshop, Strasbourg, France, 19-20 October. 2015.

Nitschke F, Held S, Villalon I, Mundhenk N, Kohl T, Neumann T. Geochemical reservoir exploration and temperature determination at the Mt. Villarrica geothermal system, Chile. In: Proceeding European Geothermal Congress 2016. European Geothermal Congress 2016, Strasbourg, France. September 19-24. 2016.

Palmer CD, Ohly SR, Smith RW, Neupane G, McLing T, Mattson E. Mineral selection for multicomponent equilibrium geothermometry. GRC Trans. 2014:38:453-9.

Pang Z-H, Reed MH. Theoretical chemical thermometry on geothermal waters: problems and methods. Geochim Cosmochim Acta. 1998;62(6):1083-91. 
Parkhurst DL, Appelo CA. Description of input for PHREEQC version 3-a computer program for speciation, batch-reaction, one-dimensional transport, and inverse geochemical calculations. 2013.

Peiffer L, Wanner C, Spycher N, Sonnenthal EL, Kennedy BM, lovenitti J. Optimized multicomponent vs. classical geothermometry: insights from modeling studies at the Dixie Valley geothermal area. Geothermics. 2014;51:154-69.

Pepin J, Person M, Phillips F, Kelley S, Timmons S, Owens L, Witcher J, Gable C. Deep fluid circulation within crystalline basement rocks and the role of hydrologic windows in the formation of the truth or consequences, New Mexico low-temperature geothermal system. Geofluids. 2015;15(1-2):139-60.

Pérez Y. Fuentes de Aguas Termales de la Cordillera Andina del Centro - Sur de Chile (39-42S). Servicio Nacional de Geología y Minería, Boletín. vol 54; 1999. p 65.

Reed M, Spycher N. Calculation of $\mathrm{pH}$ and mineral equilibria in hydrothermal waters with application to geothermometry and studies of boiling and dilution. Geochim Cosmochim Acta. 1984:48(7):1479-92.

Sánchez P, Pérez-Flores P, Arancibia G, Cembrano J, Reich M. Crustal deformation effects on the chemical evolution of geothermal systems: the intra-arc Liquine-Ofqui fault system, Southern Andes. Int Geol Rev. 2013;55(11):1384-400.

Sanjuan B, Millot R, Ásmundsson R, Brach M, Giroud N. Use of two new Na/Li geothermometric relationships for geothermal fluids in volcanic environments. Chem Geol. 2014;389:60-81.

Santoyo E, Díaz-González L. A new improved proposal of the Na/K geothermometer to estimate deep equilibrium temperatures and their uncertainties in geothermal systems. In: Proceedings World Geothermal Congress, Bali, Indonesia; 2010

Spycher N, Peiffer L, Sonnenthal EL, Saldi G, Reed MH, Kennedy BM. Integrated multicomponent solute geothermometry. Geothermics. 2014:51:113-23.

Tassi F, Aguilera F, Darrah T, Vaselli O, Capaccioni B, Poreda RJ, Delgado Huertas A. Fluid geochemistry of hydrothermal systems in the Arica-Parinacota, Tarapacá and Antofagasta regions (northern Chile). J Volcanol Geoth Res. 2010;192(1-2):1-15.

Tonani F. Some Remarks on the Application of Geochemical Techniques in geothermal exploration. In: Strub AS, Ungemach P, editors. Advances in European geothermal research. Proceedings of the second international seminar on the results of EC geothermal energy research, held in Strasbourg, 4-6 March 1980, Strasbourg; 1980.

Verma SP, Santoyo E. New improved equations for $\mathrm{Na} / \mathrm{K}, \mathrm{Na} / \mathrm{Li}$ and $\mathrm{SiO}_{2}$ geothermometers by outlier detection and rejection. J Volcanol Geotherm Res. 1997;79(1-2):9-23.

\section{Submit your manuscript to a SpringerOpen ${ }^{\odot}$ journal and benefit from:}

- Convenient online submission

- Rigorous peer review

- Open access: articles freely available online

- High visibility within the field

Retaining the copyright to your article

Submit your next manuscript at $\gg$ springeropen.com 